\title{
LINEAR LICHEN NITIDUS - A RARE CASE REPORT
}

U. S. Kanade, S. S. Dantkale, Madhuri. S. Gadhekar, H. T. Kamra

Dr. Rahul R. Narkhede.

1. Assistant Professor, Department of Pathology, Government Medical College, Latur.

2. Associate Professor and Head, Department of Pathology, Government Medical College, Latur.

3. Resident, Department of Pathology, Government Medical College, Latur.

4. Assistant Professor, Department of Pathology, Government Medical College, Latur.

5. Resident, Department of Pathology, Government Medical College, Latur.

\section{CORRESPONDING AUTHOR}

Madhuri S. Gadhekar,

Department of Pathology,

Government Medical College, Latur.

E-mail: drmadhurig@rediffmail.com,

Ph: 9108275229512.

ABSTRACT: Pinkus first described Lichen nitidus a rare variety of dermatitis of unknown etiology in 1901. Its incidence was $0.034 \%$ in a study in blacks over a 25 -years period. Various clinical variants of lichen nitidus includes- linear, confluent, vesicular, haemorrhagic, spinous follicular, perforating, generalised, palmar and plantar.

We hereby report a rare case of linear Lichen nitidus in a 17-year-old male presented with skin lesions spreading in linear fashion from anterior abdomen to back since 2 months. On examination, round, flat-topped, shiny papules, 2 to $3 \mathrm{~mm}$ in diameter presented over anterior abdomen wall extending towards back. Skin biopsy confirmed diagnosis of linear Lichen nitidus. Sections revealed vacuolar alternation of basal cell layer, diminished granular layer along with mixed-cell granulomatous infiltrate closely attached to the lower surface of the epidermis and confined to widened dermal papillae. The infiltrate composed of lymphocytes and epithelioid histiocytes. At places, rete ridges bend downward and inward and seem to clutch the infiltrate in the manner of "claw clutching a ball". Differential diagnosis of lichen striatus and lichen planus was ruled out on histopathology. Patient responded to treatment.

KEYWORDS: Lichen nitidus, Lichen striatus, Lichen planus.

INTRODUCTION: Pinkus first described Lichen nitidus $\{L N\}$, a rare variety of dermatitis of unknown etiology in 1901.[1] It is characterised by the presence of shiny, domeshaped papules, which usually are asymptomatic. [2] Many clinical variants of LN have been reported. We hereby report a rare case of lichen nitidus, linear variant.

CASE HISTORY: A 17-year-old male presented with chief complaints of skin lesions since 2 months. Clinical examination revealed multiple, round, flat-topped, shiny papules, 2 to $3 \mathrm{~mm}$ in diameter over anterior abdomen wall spreading in linear fashion towards the back (fig. 1). There was no history of any prior medication, diarrhoea, constipation, joint pain, similar complaints in family members. Routine laboratory investigations were within normal limits. Clinical differential diagnoses were lichen striatus and lichenoid epidermal naevus. Skin biopsy was taken from papules with help of $5 \mathrm{~mm}$ biopsy punch. Histopathological examination showed epidermis with diminished granular layer, along with basal cell layer vacuolization. Focal granulomatous infiltrate was seen closely attached to the lower epidermis and confined to widened dermal papillae (fig. 2). The 
infiltrate was composed of predominantly lymphocytes and few epithelioid histiocytes. At places, rete ridges were to extend downward and seem to clutch the infiltrate in manner of "claw clutching a ball" (fig. 3). The diagnosis of LN was made.

DISCUSSION: LN is chronic papulosquamous disorder characterized by multiple, 1-2 mm, flesh-colored, shiny, dome-shaped papules.[3] Its incidence is $0.034 \%$ in a study of skin diseases in blacks over a 25-years period.[4] Skin lesions classically involves the genitalia, upper extremities, chest and abdomen. Infrequently, the lower extremities, palms, soles, face, nails, and mucous membranes may be affected. Majority of cases are common in children and young adults. Various clinical variants of lichen nitidus are - linear, confluent, vesicular, haemorrhagic, spinous follicular, perforating, generalised, palmar and plantar.[5]

Our patient was 17 year old male presenting with shiny papules over anterior abdomen wall spreading in linear fashion towards the back representing a linear variant.

Few cases of $\mathrm{LN}$ are reported in association with other diseases such as atopic dermatitis, Crohns disease[6], juvenile chronic arthritis[7] and down syndrome.[8, 9] Familial cases have been described.[10] Our patient had no such association.

LN must be differentiated from lichen striatus, lichenoid epidermal naevus, lichen planus and keratosis pilaris, lichen spinulosus on microscopic examination.

The absence of irregular acanthosis, wedge-shaped hypergranulosis, and compact orthokeratosis, helped us to differentiate LN from lichen planus.

LN is distinguished from Lichen striatus, which shows superficial perivascular lymphocytic infiltrate and inflammatory infiltrate around hair follicles and eccrine glands.

Both keratosis pilaris and Lichen spinulosus show epidermal hyperkeratosis, hypergranulosis, and plugging of individual hair follicles with keratinous plugs, and thus discriminate them from $L N$.

No evidence of hyperkeratosis, papillomatosis and acanthosis ruled out lichenoid epidermal naevus.[11]

Aetiology of lichen nitidus remains unresolved. In view of similar ultrastructural findings and possible clinical coexistence, lichen nitidus, is considered by some authors, to be a variant of lichen planus. [12] However, the papule in lichen nitidus develop epidermal flattening and parakeratosis, unlike in lichen planus where it develops into acanthosis and hyperkeratosis. [13]

On follow up, there was remission of lesion after treatment with local potent steroids (fig.4).

Such rare cases may be easily missed, histopathology helps differentiation from other papulosquamous disorders, provide a definitive diagnosis and thus aid appropriate management. 


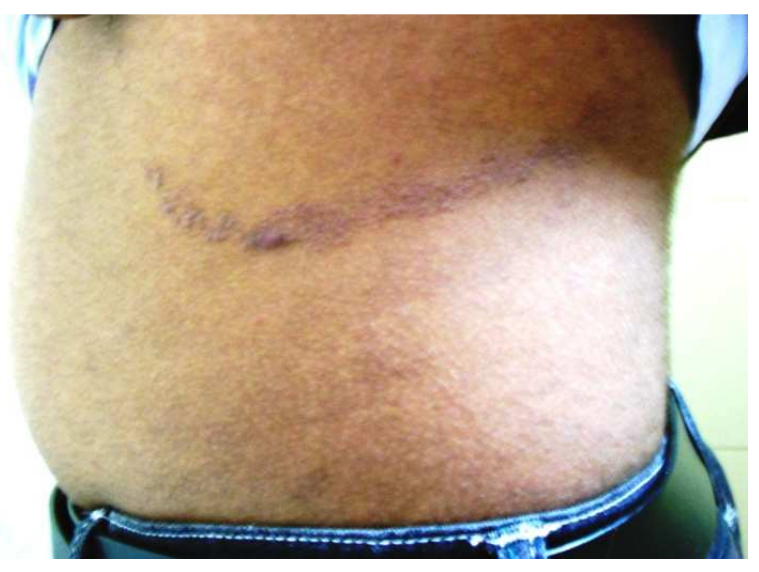

Figure1. Multiple papules present over anterior abdomen spreading in linear fashion towards the back.

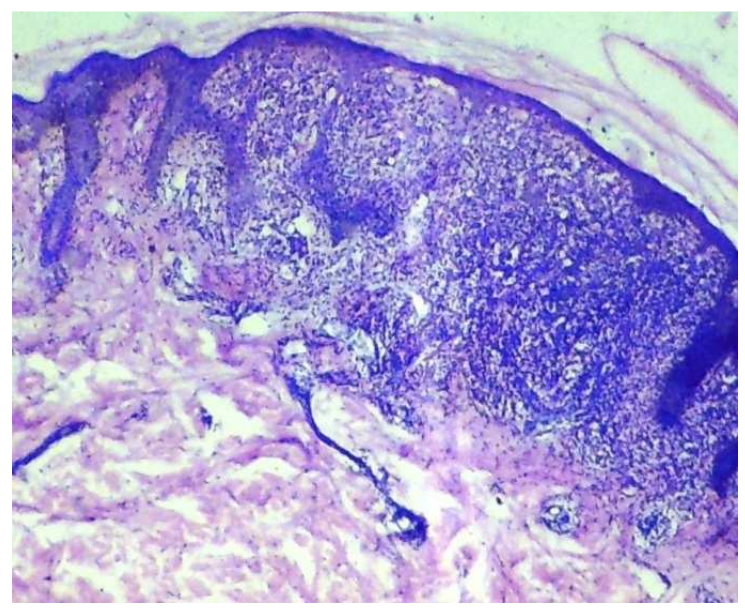

Figure 2. Rete ridges clutch the infiltrate in manner of "claw clutching a ball".

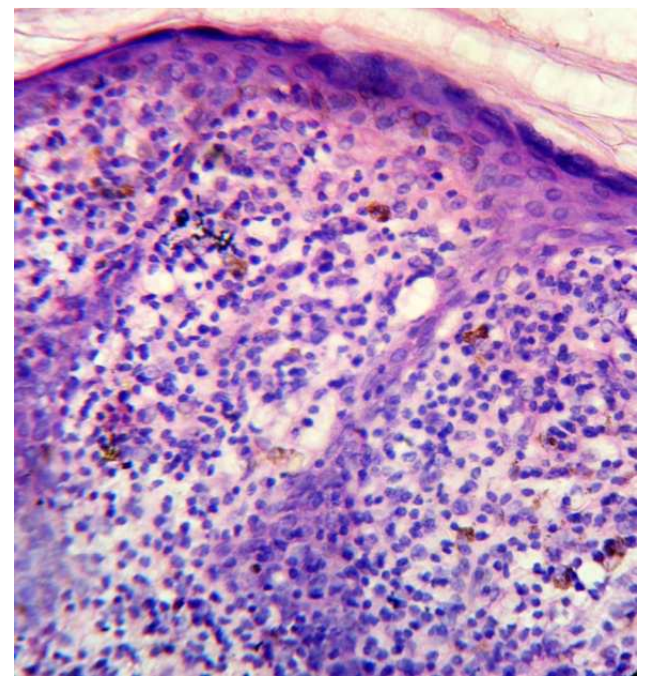

Figure 3. Dense lymphohistiocytic infiltrate in widened dermal papillae. 


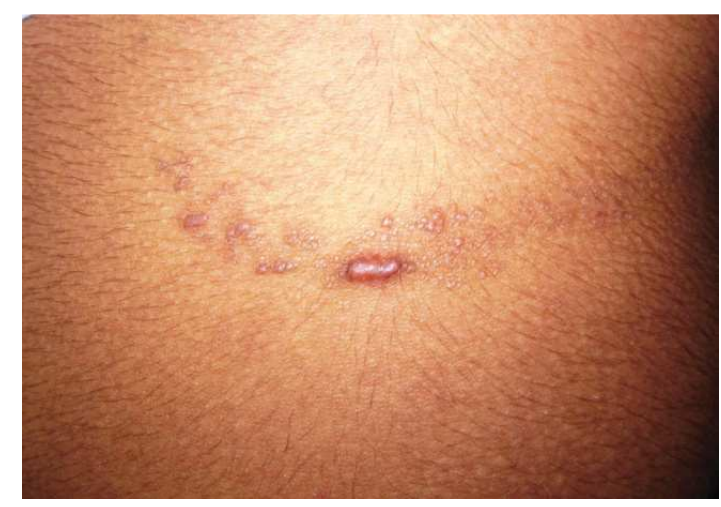

Figure 4. Patient on treatment with potent local steroids.

\section{REFERENCES:}

1. Chen W, Schranm M, Zouboulis CC. Generalised lichen nitidus. J Am Acad Dermatol. 1997; 36:630-1.[PubMed: 9092753].

2. David E. Elder, Bernett L. Johnson, Rosalie Elenitsas. Lever's Histopathology of the Skin. 9th Edition. Philadelphia. Lippincott Williams \& Wilkins. 2005

3. Inamadar AC, Athanikar SB, Sampagavi W, Yelikar BR. Actinic lichen nitidus.Indian J Dermatol Venereol Leprol 2001;67:209-210

4. Hazen HH. Syphilis and skin diseases in the American Negro: personal observations. Arch Dermatol Syph. 1935; 31:316.

5. Black MM. Lichen planus and lichenoid disorders. In: Textbook of Dermatology (Eds: Champion RH, Burton JL, Ebling FJG) 5th edn, vol 3. Oxford; Blackwell Scientific Publication, 1992; 1996-1998.

6. Kano Y, Shiohara T, Yagita A, Nagashima M. Erythema nodosum, lichen planus and lichen nitidus in Crohn's disease: report of a case and analysis of $\mathrm{T}$ cell receptor $\mathrm{V}$ gene expression in the cutaneous and intestinal lesions. Dermatology. 1995; 190(1):59-63.

7. Bercedo A, Cabero MJ, Garcia-Consuegra J, Hernado M, Yaez S, FernandezLlaca H. Generalized lichen nitidus and juvenile chronic arthritis: an undescribed association. Pediatr Dermatol. Sep-Oct 1999; 16(5):406-7.

8. Henry M, Metry DW. Generalized lichen nitidus, with perioral and perinasal accentuation, in association with Down syndrome. Pediatr Dermatol. Jan-Feb 2009; 26(1):109-11.

9. Laxmisha C, Thappa DM. Generalized lichen nitidus with Down syndrome. J Eur Acad Dermatol Venereol 2006;20:1156-7.

10. Kato N. Familial lichen nitidus. Clin Exp Dermatol. Jul 1995;20(4):336-8.

11. Brownstein $\mathrm{MH}$, Silverstein L, Lefing W Lichenoid epidermal nevus: "linear lichen planus" J Am Acad Dermatol. 1989 May; 20(5 Pt 2):913-15.

12. Stankler L. The identity of lichen planus and lichen nitidus. Br J Dermatol. 1967;79: 125-6.[PubMed: 6019108]

13. David E. Elder, Bernett L. Johnson, Rosalie Elenitsas. Lever's Histopathology of the Skin. 10th Edition. Philadelphia: Lippincott Williams \& Wilkins; 2005 page 192 